\title{
INCLUSION OF ANNATTO SEED BY-PRODUCT IN DIETS CONTAINING SORGHUM FOR SLOW-GROWTH BROILERS
}

\author{
Inclusão do resíduo da semente do urucum em rações contendo sorgo para \\ frangos de corte de crescimento lento
}

\author{
Davyd Herik Souza ${ }^{1}$, Ednardo Rodrigues Freitas ${ }^{2}$, Edibergue Oliveira dos Santos ${ }^{2}$, \\ Rafaela Maia Cipriano ${ }^{2}$, Carlos Weiber Silva Figueiredo ${ }^{2}$, Francisco Diego Teixeira Dantas ${ }^{2}$
}

\begin{abstract}
Sorghum is used as a source of energy alternative to corn, however, its low pigments content are considered hindrance to the use of this feedstuff for poultry. The inclusion of annatto seed by-product (ASB) may solve this problem. In this context, the objective of this study was to evaluate the effect of ASB inclusion in diets containing sorghum as the main source of energy on performance, carcass traits, meat color, and economic viability in the production of slow-growth broilers. A total of 420 sexed chicks of the Carijó Pesadão line were distributed in a completely randomized design according to a $2 \times 7$ factorial arrangement, with three replicates of 10 birds per treatment. Studied factors were two sexes (males and females) and seven diets, wherein one had corn as source of energy and the others contained sorghum plus inclusion of $0,3,6,9,12$, and $15 \%$ of ASB. Irrespective of the sex, diets did not affect feed intake ( $\mathrm{g} /$ bird), feed conversion $(\mathrm{g} / \mathrm{g})$, yields $(\%)$ of carcass, breast and drumstick + thigh, percentage of abdominal fat, or relative weight of the liver. However, the inclusion of ASB influenced the color parameters of the meat making it more pigmented and improved the economic viability parameters. In diets for slow-growth birds containing sorghum as the main source of energy, ASB can be included up to $15 \%$, and meat pigmentation problems can be reduced with total substitution of corn by sorghum with inclusion of ASB from $3 \%$.
\end{abstract}

Index terms: Alternative feedstuff; weight gain; natural pigment.

\section{RESUMO}

O sorgo é utilizado como fonte de energia alternativa ao milho, no entanto, seu baixo teor de pigmentos é considerado entrave na utilização desse ingrediente para aves. A inclusão do resíduo da semente do urucum (ASB) pode solucionar esse problema. Nesse contexto, objetivou-se avaliar o efeito da inclusão do ASB em rações contendo sorgo como principal fonte de energia sobre o desempenho, características de carcaça, coloração da carne e viabilidade econômica na produção de frangos de corte de crescimento lento. Foram utilizados 420 pintos sexados da linhagem carijó pesadão, distribuídos em delineamento inteiramente casualizado, segundo o esquema fatorial $2 \times 7, \operatorname{com} 3$ repetições de 10 aves por tratamento. Os fatores estudados foram 2 sexos (machos e fêmeas) e 7 rações, sendo uma ração composta por milho como fonte de energia e as demais contendo sorgo e a inclusão de $0 ; 3 ; 6 ; 9 ; 12$; e $15 \%$ do ASB. Independente do sexo, as rações não influenciaram o consumo de ração (g/ave), ganho de peso (g/ave), conversão alimentar $(\mathrm{g} / \mathrm{g})$, rendimento (\%) de carcaça, peito, coxa+sobrecoxa, porcentagem de gordura abdominal e peso relativo do fígado. Entretanto, a inclusão do ASB influenciou os parâmetros de cor da carne, tornando-a mais pigmentada, e melhorou os parâmetros de viabilidade econômica. Em rações para aves de crescimento lento contendo sorgo como principal fonte de energia, pode-se incluir até $15 \%$ do ASB, sendo possível reduzir os problemas de pigmentação da carne, em decorrência da substituição total do milho pelo sorgo com a inclusão do ASB a partir de 3\%.

Termos para indexação: Alimento alternativo; ganho de peso; pigmentante natural.

\section{INTRODUCTION}

In poultry diets, corn is the most widely used energetic ingredient, as it provides approximately $65 \%$ of the metabolizable energy and $20 \%$ of the protein, sometimes composing around $60 \%$ of the diet supplied to these animals. Depending on the time of the year, this ingredient may account for approximately $40 \%$ of the production cost (Gomes et al., 2007). This has been causing preoccupation among producers and researchers, who, in an attempt to reduce the feed cost, constantly seek alternative ingredients for diet formulation.

Among the alternative feedstuffs, sorghum is commonly used as a source of energy alterative to corn. Despite the nutritional traits and economic viability attributed to sorghum, its low xanthophyll and carotene contents are considered the main hindrance to the use of this feedstuff in poultry diets. Though they do not provide

${ }^{1}$ Universidade Federal do Ceará/UFC - Departamento de Zootecnia - Av. Mister Hull - 2977 - Campos do Pici - Bloco 808 - $60021-970$ - Fortaleza CE - Brasil - davyd.hsouza@hotmail.com

${ }^{2}$ Universidade Federal do Ceará/UFC - Departamento de Zootecnia - Fortaleza - CE - Brasil

Received in february 11, 2015 and approved march 20, 2015

Ciênc. Agrotec., Lavras, v.39, n.3, p.248-259, maio/jun., 2015 
nutritional value, these pigments gives the yellow-orangish color to the skin and meat of broilers, which is an important characteristic for the consumer preference (Garcia et al., 2005). Both artificial and natural pigments have been added to poultry diets aiming to fix this problem. However, because of consumers' restriction and the rigorous legislation of developed countries in recent years, which prohibit the addition of synthetic pigments to animal diets and human food, the option of using natural pigments has grown (Moreno et al., 2007).

In this scenario, among the tested natural pigments, those deriving from annatto seed (Bixa orellana L.) have stood out in both human and animal feeding. Consequently, the processing of annatto seed in the different regions of Brazil has increased. In obtaining the paprika and extracting the pigments for the industry of natural colorants, approximately $97 \%$ to $98 \%$ of the crude annatto seed is unused, becoming a waste that may pollute the environment when disposed of by industries (Silva et al., 2006). This processing waste, named annatto seed by-product (ASB), also has a red color, and its chemical composition values indicate that it can be used in animal feeding. Thus, the objective of this study was to evaluate the effect of inclusion of ASB in diets containing sorghum as the main source of energy on performance, carcass traits, meat color, and economic viability in slow-growth-broiler production.

\section{MATERIAL AND METHODS}

The study was conducted in a conventional shed divided into 48 pens measuring $1.5 \mathrm{~m} \times 1.0 \mathrm{~m}$. A total of 420 sexed day-old chicks of the Carijó Pesadão line were distributed in a completely randomized design according to a $2 \times 7$ factorial arrangement with three replicates of 10 birds per treatment. Studied factors were two sexes (male and female) and seven diets, wherein one had corn as the source of energy and the others contained sorghum as source of energy plus inclusion of $0,3,6,9,12$, and $15 \%$ ASB.

The feeding program consisted of three phases: the starter phase (1 to 28 days), the grower phase ( 28 to 56 days) and the finisher phase (56 to 78 days). To calculate the experimental diets, the feed composition values presented by Rostagno et al. (2011) were considered, except for ASB, which contained $88.77 \%$ dry matter, $2,058 \mathrm{kcal} /$ $\mathrm{kg}$ (starter phase) and 2,813 kcal/kg (grower and finisher phases) of metabolizable energy corrected for the nitrogen balance, $13.46 \%$ crude protein, $12.81 \%$ acid detergent fiber, $32.94 \%$ neutral detergent fiber, $1.65 \%$ ether extract, $3.14 \%$ mineral matter, $0.18 \%$ calcium, $0.31 \%$ phosphorus, $0.61 \%$ total lysine, $0.21 \%$ total methionine, $0.38 \%$ total methionine+cystine, $0.09 \%$ total tryptophan, and $0.41 \%$ total threonine (values expressed in the fresh matter).

The nutritional requirements considered in the formulation were those proposed in the National Research Council - NRC (1994) for broilers. For each rearing phase, the diets (Tables 1, 2, and 3) were formulated to be isonutritive and isoenergetic. Throughout the entire experimental period, birds received feed and water $a d$ libitum and were maintained under a lighting program of $24 \mathrm{~h}$ of light until the end of the starter phase, and then under natural light only. Temperature and relative air humidity data were collected in the early morning (8:00 am) and late afternoon (4:00 pm) using a digital thermohygrometer, minimum and maximum mean values for room temperature and relative air humidity during the experimental period were $27.66{ }^{\circ} \mathrm{C}$ and $31.56{ }^{\circ} \mathrm{C}$ and $47.37 \%$ and $70.64 \%$, respectively.

Studied variables were feed intake ( $\mathrm{g} / \mathrm{bird})$, weight gain ( $\mathrm{g} / \mathrm{bird})$, feed conversion ( $\mathrm{g} / \mathrm{g})$, yields $(\%)$ of carcass, breast, drumstick+thigh and abdominal fat (\%), relative weight of the liver (\%), meat color, cost of diet $(\mathrm{R} \$ / \mathrm{kg}$ gained), economic efficiency index (\%) and cost index (\%).

At the end of the experimental period (birds at 78 days of age), two birds from each plot were selected based on the plot's average weight, for slaughtering and evaluation of carcass characteristics. The chosen birds were identified and, after an 8-hour feed-deprivation period, they were slaughtered by cervical dislocation, bled, skinned (water at $60{ }^{\circ} \mathrm{C}$ for $3 \mathrm{~min}$ ), plucked, and eviscerated. Carcasses without head, neck, legs and viscera were weighed to determine the carcass yield in relation to the birds fasted body weight. Subsequently the carcasses were sectioned and the parts were weighed to determine the yields of breast and drumstick + thigh, and the percentage of abdominal fat, which were calculated as a function of the hot carcass weight. The relative weight of the liver was calculated as the ratio between the absolute weight of that organ and the body weight of the fasted bird.

To evaluate the color of the birds' breasts and thighs, through objective measurements, a Minolta CR300 colorimeter (Tokyo) was used, operating in the CIE ( $\mathrm{L}^{*}$, $a^{*}$, and $b^{*}$ ) system, wherein $L^{*}$ is the lightness, which varies in a scale from 0 (black) to 100 (white); $a^{*}$ is the color intensity that varies from green $(-60)$ to red $(+60)$; and $\mathrm{b}^{*}$ corresponds to the color intensity that varies from blue $(-60)$ to yellow $(+60)$ (Shimokomaki et al., 2006). For the assessment, the measuring probe was placed in contact with the surface of the muscle from the breast and thigh at three different points, and the average was calculated for each portion. 
Table 1: Composition, and nutritional and energy contents of experimental diets for slow-growth broilers in the phase from 1 to 28 days of age.

\begin{tabular}{|c|c|c|c|c|c|c|c|}
\hline \multirow{2}{*}{ Ingredient (kg) } & \multicolumn{7}{|c|}{ ASB inclusion level (\%) } \\
\hline & 0 & 0 & 3 & 6 & 9 & 12 & 15 \\
\hline Corn & 61.59 & 0.00 & 0.00 & 0.00 & 0.00 & 0.00 & 0.00 \\
\hline Sorghum & 0.00 & 61.15 & 57.86 & 54.57 & 51.27 & 47.97 & 44.70 \\
\hline Soybean meal (45\%) & 33.50 & 32.05 & 31.81 & 31.57 & 31.33 & 31.09 & 30.84 \\
\hline Annatto seed by-product & 0.00 & 0.00 & 3.00 & 6.00 & 9.00 & 12.00 & 15.00 \\
\hline Soybean oil & 1.17 & 3.02 & 3.57 & 4.12 & 4.68 & 5.23 & 5.78 \\
\hline Calcitic limestone & 1.09 & 1.14 & 1.15 & 1.16 & 1.17 & 1.18 & 1.19 \\
\hline Dicalcium phosphate & 1.62 & 1.57 & 1.54 & 1.50 & 1.47 & 1.44 & 1.40 \\
\hline Min./vit. supplement ${ }^{1}$ & 0.20 & 0.20 & 0.20 & 0.20 & 0.20 & 0.20 & 0.20 \\
\hline Common salt & 0.48 & 0.48 & 0.48 & 0.49 & 0.49 & 0.49 & 0.49 \\
\hline DL-methionine & 0.20 & 0.24 & 0.24 & 0.24 & 0.24 & 0.25 & 0.25 \\
\hline Choline chloride & 0.05 & 0.05 & 0.05 & 0.05 & 0.05 & 0.05 & 0.05 \\
\hline Bacitracin zinc & 0.05 & 0.05 & 0.05 & 0.05 & 0.05 & 0.05 & 0.05 \\
\hline Salinomycin & 0.05 & 0.05 & 0.05 & 0.05 & 0.05 & 0.05 & 0.05 \\
\hline TOTAL & 100.00 & 100.00 & 100.00 & 100.00 & 100.00 & 100.00 & 100.00 \\
\hline \multicolumn{8}{|c|}{ Calculated nutritional and energy content } \\
\hline Metabolizable energy (kcal/kg) & 2.950 & 2.950 & 2.950 & 2.950 & 2.950 & 2.950 & 2.950 \\
\hline Crude protein $(\%)$ & 20.12 & 20.12 & 20.12 & 20.12 & 20.12 & 20.12 & 20.12 \\
\hline Dry matter (\%) & 88.40 & 88.87 & 88.91 & 88.95 & 88.99 & 89.03 & 89.07 \\
\hline Ether extract $(\%)$ & 3.98 & 5.36 & 5.85 & 6.35 & 6.86 & 7.35 & 7.85 \\
\hline Acid detergent fiber $(\%)$ & 4.78 & 6.19 & 6.36 & 6.53 & 6.71 & 6.88 & 7.05 \\
\hline Neutral detergent fiber (\%) & 11.97 & 10.55 & 11.18 & 11.80 & 12.43 & 13.05 & 13.68 \\
\hline Calcium (\%) & 0.92 & 0.92 & 0.92 & 0.92 & 0.92 & 0.92 & 0.92 \\
\hline Available phosphorus (\%) & 0.41 & 0.41 & 0.41 & 0.41 & 0.41 & 0.41 & 0.41 \\
\hline Sodium (\%) & 0.21 & 0.21 & 0.21 & 0.21 & 0.21 & 0.21 & 0.21 \\
\hline Chlorine (\%) & 0.34 & 0.33 & 0.33 & 0.33 & 0.33 & 0.33 & 0.33 \\
\hline Potassium (\%) & 0.79 & 0.79 & 0.78 & 0.76 & 0.75 & 0.73 & 0.72 \\
\hline Total lysine $(\%)$ & 1.08 & 1.02 & 1.02 & 1.03 & 1.03 & 1.04 & 1.04 \\
\hline Total methionine + cystine $(\%)$ & 0.83 & 0.83 & 0.83 & 0.82 & 0.83 & 0.83 & 0.83 \\
\hline Total methionine (\%) & 0.50 & 0.52 & 0.52 & 0.52 & 0.52 & 0.53 & 0.53 \\
\hline Total threonine $(\%)$ & 0.79 & 0.75 & 0.75 & 0.74 & 0.74 & 0.74 & 0.74 \\
\hline Total tryptophan (\%) & 0.25 & 0.26 & 0.26 & 0.26 & 0.26 & 0.25 & 0.25 \\
\hline
\end{tabular}

${ }^{1}$ Guaranteed level per kg of product: 5,500,000 IU vitamin A, $500 \mathrm{mg}$ vitamin B1, 7,500 mcg vitamin B12, 2,502 mg vitamin B2, $750 \mathrm{mg}$ vitamin B6, 1,000,000 IU vitamin D3, 6,500 IU vitamin E, 1,250 mg vitamin K3, $25 \mathrm{mg}$ biotin, $17.5 \mathrm{~g}$ niacin, $251 \mathrm{mg}$ folic acid, $6,030 \mathrm{mg}$ pantothenic acid, $50 \mathrm{mg}$ cobalt, 3,000 mg copper, $25 \mathrm{~g}$ iron, $500 \mathrm{mg}$ iodine, $32.5 \mathrm{~g}$ manganese, $100.05 \mathrm{mg}$ selenium, $22.49 \mathrm{~g}$ zinc. 
Table 2: Composition, and nutritional and energy contents of experimental diets for slow-growth broilers in the phase from 28 to 56 days of age.

\begin{tabular}{|c|c|c|c|c|c|c|c|}
\hline \multirow{2}{*}{ Ingredient (kg) } & \multicolumn{7}{|c|}{ ASB inclusion level (\%) } \\
\hline & 0 & 0 & 3 & 6 & 9 & 12 & 15 \\
\hline Corn & 67.24 & 0.00 & 0.00 & 0.00 & 0.00 & 0.00 & 0.00 \\
\hline Sorghum & 0.00 & 66.75 & 63.99 & 61.22 & 58.45 & 55.67 & 52.89 \\
\hline Soybean meal (45\%) & 27.71 & 26.05 & 25.72 & 25.39 & 25.06 & 24.72 & 24.38 \\
\hline Annatto seed by-product & 0.00 & 0.00 & 3.00 & 6.00 & 9.00 & 12.00 & 15.00 \\
\hline Soybean oil & 1.73 & 3.80 & 3.93 & 4.06 & 4.19 & 4.32 & 4.46 \\
\hline Calcitic limestone & 1.36 & 1.41 & 1.42 & 1.43 & 1.44 & 1.46 & 1.47 \\
\hline Dicalcium phosphate & 1.13 & 1.08 & 1.04 & 1.01 & 0.97 & 0.94 & 0.91 \\
\hline Min./vit. supplement ${ }^{1}$ & 0.20 & 0.20 & 0.20 & 0.20 & 0.20 & 0.20 & 0.20 \\
\hline Common salt & 0.41 & 0.41 & 0.41 & 0.41 & 0.41 & 0.41 & 0.41 \\
\hline DL-methionine & 0.07 & 0.11 & 0.11 & 0.11 & 0.11 & 0.11 & 0.11 \\
\hline L-lysine HCL & 0.00 & 0.04 & 0.03 & 0.03 & 0.02 & 0.02 & 0.02 \\
\hline Choline chloride & 0.05 & 0.05 & 0.05 & 0.05 & 0.05 & 0.05 & 0.05 \\
\hline Bacitracin zinc & 0.05 & 0.05 & 0.05 & 0.05 & 0.05 & 0.05 & 0.05 \\
\hline Salinomycin & 0.05 & 0.05 & 0.05 & 0.05 & 0.05 & 0.05 & 0.05 \\
\hline TOTAL & 100.00 & 100.00 & 100.00 & 100.00 & 100.00 & 100.00 & 100.00 \\
\hline \multicolumn{8}{|c|}{ Calculated nutritional and energy content } \\
\hline Metabolizable energy (kcal/kg) & 3.050 & 3.050 & 3.050 & 3.050 & 3.050 & 3.050 & 3.050 \\
\hline Crude protein $(\%)$ & 17.87 & 17.87 & 17.87 & 17.87 & 17.87 & 17.87 & 17.87 \\
\hline Dry matter (\%) & 88.35 & 88.87 & 88.86 & 88.85 & 88.84 & 88.83 & 88.82 \\
\hline Ether extract (\%) & 4.64 & 6.20 & 6.29 & 6.38 & 6.48 & 6.57 & 6.66 \\
\hline Acid detergent fiber $(\%)$ & 4.51 & 6.04 & 6.23 & 6.43 & 6.62 & 6.82 & 7.00 \\
\hline Neutral detergent fiber (\%) & 11.84 & 10.29 & 10.95 & 11.62 & 12.28 & 12.94 & 13.61 \\
\hline Calcium (\%) & 0.89 & 0.89 & 0.89 & 0.89 & 0.89 & 0.89 & 0.89 \\
\hline Available phosphorus (\%) & 0.31 & 0.31 & 0.31 & 0.31 & 0.31 & 0.31 & 0.31 \\
\hline Sodium (\%) & 0.18 & 0.18 & 0.18 & 0.18 & 0.18 & 0.18 & 0.18 \\
\hline Chlorine $(\%)$ & 0.29 & 0.29 & 0.29 & 0.29 & 0.29 & 0.29 & 0.29 \\
\hline Potassium (\%) & 0.70 & 0.70 & 0.69 & 0.67 & 0.66 & 0.64 & 0.63 \\
\hline Total lysine (\%) & 0.93 & 0.89 & 0.89 & 0.89 & 0.89 & 0.89 & 0.89 \\
\hline Total methionine + cystine (\%) & 0.64 & 0.64 & 0.64 & 0.64 & 0.64 & 0.64 & 0.64 \\
\hline Total methionine (\%) & 0.34 & 0.36 & 0.36 & 0.36 & 0.37 & 0.37 & 0.37 \\
\hline Total threonine $(\%)$ & 0.71 & 0.66 & 0.65 & 0.65 & 0.65 & 0.65 & 0.65 \\
\hline Total tryptophan (\%) & 0.21 & 0.23 & 0.23 & 0.23 & 0.22 & 0.22 & 0.22 \\
\hline
\end{tabular}

${ }^{1}$ Guaranteed level per kg of product: 5,500,000 IU vitamin A, $500 \mathrm{mg}$ vitamin B1, 7,500 mcg vitamin B12, 2,502 mg vitamin B2, $750 \mathrm{mg}$ vitamin B6, 1,000,000 IU vitamin D3, 6,500 IU vitamin E, 1,250 mg vitamin K3, $25 \mathrm{mg}$ biotin, $17.5 \mathrm{~g}$ niacin, $251 \mathrm{mg}$ folic acid, 6,030 mg pantothenic acid, $50 \mathrm{mg}$ cobalt, 3,000 mg copper, $25 \mathrm{~g}$ iron, $500 \mathrm{mg}$ iodine, $32.5 \mathrm{~g}$ manganese, $100.05 \mathrm{mg}$ selenium, $22.49 \mathrm{~g}$ zinc. 
Table 3: Composition, and nutritional and energy contents of experimental diets for slow-growth broilers in the phase from 56 to 78 days of age.

\begin{tabular}{|c|c|c|c|c|c|c|c|}
\hline \multirow{2}{*}{ Ingredient $(\mathrm{kg})$} & \multicolumn{7}{|c|}{ ASB inclusion level (\%) } \\
\hline & 0 & 0 & 3 & 6 & 9 & 12 & 15 \\
\hline Corn & 66.97 & 0.00 & 0.00 & 0.00 & 0.00 & 0.00 & 0.00 \\
\hline Sorghum & 0.00 & 66.45 & 63.68 & 60.92 & 58.14 & 55.37 & 52.61 \\
\hline Soybean meal (45\%) & 26.97 & 25.43 & 25.09 & 24.74 & 24.40 & 24.05 & 23.71 \\
\hline Annatto seed by-product & 0.00 & 0.00 & 3.00 & 6.00 & 9.00 & 12.00 & 15.00 \\
\hline Soybean oil & 3.16 & 5.21 & 5.34 & 5.47 & 5.60 & 5.74 & 5.87 \\
\hline Calcitic limestone & 1.14 & 1.18 & 1.19 & 1.20 & 1.22 & 1.23 & 1.24 \\
\hline Dicalcium phosphate & 1.08 & 1.03 & 1.00 & 0.96 & 0.93 & 0.90 & 0.86 \\
\hline Min./vit. supplement ${ }^{1}$ & 0.15 & 0.15 & 0.15 & 0.15 & 0.15 & 0.15 & 0.15 \\
\hline Common salt & 0.38 & 0.38 & 0.38 & 0.39 & 0.39 & 0.39 & 0.39 \\
\hline DL-methionine & 0.05 & 0.07 & 0.07 & 0.07 & 0.07 & 0.07 & 0.07 \\
\hline Choline chloride & 0.05 & 0.05 & 0.05 & 0.05 & 0.05 & 0.05 & 0.05 \\
\hline Bacitracin zinc & 0.05 & 0.05 & 0.05 & 0.05 & 0.05 & 0.05 & 0.05 \\
\hline TOTAL & 100.00 & 100.00 & 100.00 & 100.00 & 100.00 & 100.00 & 100.00 \\
\hline \multicolumn{8}{|c|}{ Calculated nutritional and energy content } \\
\hline Metabolizable energy $(\mathrm{kcal} / \mathrm{kg})$ & 3.150 & 3.150 & 3.150 & 3.150 & 3.150 & 3.150 & 3.150 \\
\hline Crude protein $(\%)$ & 17.50 & 17.50 & 17.50 & 17.50 & 17.50 & 17.50 & 17.50 \\
\hline Dry matter $(\%)$ & 88.47 & 88.98 & 88.97 & 88.96 & 88.95 & 88.94 & 88.93 \\
\hline Ether extract (\%) & 6.05 & 7.59 & 7.68 & 7.77 & 7.86 & 7.96 & 8.05 \\
\hline Acid detergent fiber $(\%)$ & 4.44 & 5.97 & 6.17 & 6.36 & 6.55 & 6.74 & 6.94 \\
\hline Neutral detergent fiber $(\%)$ & 11.71 & 10.17 & 10.83 & 11.50 & 12.16 & 12.82 & 13.49 \\
\hline Calcium (\%) & 0.79 & 0.79 & 0.79 & 0.79 & 0.79 & 0.79 & 0.79 \\
\hline Available phosphorus (\%) & 0.30 & 0.30 & 0.30 & 0.30 & 0.30 & 0.30 & 0.30 \\
\hline Sodium (\%) & 0.17 & 0.17 & 0.17 & 0.17 & 0.17 & 0.17 & 0.17 \\
\hline Chlorine $(\%)$ & 0.28 & 0.27 & 0.27 & 0.27 & 0.27 & 0.27 & 0.27 \\
\hline Potassium (\%) & 0.69 & 0.69 & 0.67 & 0.66 & 0.64 & 0.63 & 0.61 \\
\hline Total lysine $(\%)$ & 0.91 & 0.84 & 0.84 & 0.85 & 0.85 & 0.85 & 0.86 \\
\hline Total methionine + cystine $(\%)$ & 0.62 & 0.59 & 0.59 & 0.59 & 0.59 & 0.59 & 0.59 \\
\hline Total methionine (\%) & 0.32 & 0.32 & 0.32 & 0.32 & 0.32 & 0.32 & 0.32 \\
\hline Total threonine $(\%)$ & 0.69 & 0.64 & 0.64 & 0.64 & 0.64 & 0.64 & 0.64 \\
\hline Total tryptophan (\%) & 0.21 & 0.23 & 0.22 & 0.22 & 0.22 & 0.22 & 0.22 \\
\hline
\end{tabular}

${ }^{1}$ Guaranteed level per kg of product: 5,500,000 IU vitamin A, $500 \mathrm{mg}$ vitamin B1, 7,500 mcg vitamin B12, 2,502 mg vitamin B2, $750 \mathrm{mg}$ vitamin B6, 1,000,000 IU vitamin D3, 6,500 IU vitamin E, 1,250 mg vitamin K3, $25 \mathrm{mg}$ biotin, $17.5 \mathrm{~g}$ niacin, $251 \mathrm{mg}$ folic acid, $6,030 \mathrm{mg}$ pantothenic acid, $50 \mathrm{mg}$ cobalt, 3,000 mg copper, $25 \mathrm{~g}$ iron, $500 \mathrm{mg}$ iodine, $32.5 \mathrm{~g}$ manganese, $100.05 \mathrm{mg}$ selenium, $22.49 \mathrm{~g}$ zinc. 
To check the economic viability of substituting corn for sorghum and including levels of ASB in the diets, the cost of diet (CD) per kilogram of live weight gain was determined according to the equation proposed by Bellaver et al. (1985). Next, the economic efficiency index (EEI) and the cost index (CI) proposed by Fialho et al. (1992) were calculated. Only the prices of the ingredients were considered in the calculation, as follows: 0.80, 1.60, 0.56, 0.50 and 2.80 Brazilian Reais (R\$) for the kilogram of corn, soybean meal, sorghum, ASB and soybean oil, respectively, which were the prices adopted at the time of the experiment in the city of Fortaleza/ CE, Brazil.

The data were analyzed statistically on the Statistical Analyses System software (SAS, 2000). Treatments data were initially subjected to analysis of variance in a factorial arrangement ( 2 sexes $\times 7$ diets). Means between the diets were compared by the SNK test $(5 \%)$ and means between the sexes were compared by the F test $(5 \%)$. Next, a regression analysis was performed for the data obtained with the different inclusion levels of ASB.

\section{RESULTS AND DISCUSSION}

The average results for feed intake (FI, g/bird), weight gain (WG, g/bird) and feed conversion (FC, g/g) of the slow-growth broilers are shown in Table 4. In the analysis of variance, it was found that there was no significant difference between the factors sex and diets on FI, WG and FC in any of the performance evaluation phases. It was also observed that the diets did not influence these variables significantly in the different phases. However, there was a difference between the sexes for FI and WG in all evaluated phases, and in FC in the phases from 1 to 56 and from 1 to 78 days of age. According to the regression analysis, inclusion of ASB from $3 \%$ did not affect FI, WG, or FC significantly in any of the performance evaluation phases.

The obtained results indicate that similarly to what has been reported for fast-growth broilers (Garcia et al., 2005; Rocha et al., 2008), sorghum can be used as a total substitute to corn in the feeding of slow-growth broilers without impairing the animal performance. It is known that the metabolizable energy has been reported to be the main dietary factor affecting voluntary feed intake by birds (Freitas et al., 2011); thus, it can be inferred that the absence of a significant effect of inclusion of ASB on FI and consequently on WG and FC may be associated with the good evaluation of the feed's metabolizable energy, since diets were calculated to be isoenergetic, considering the metabolizable energy values of ASB determined for slow-growth broilers at different ages.

The effects obtained for inclusion of ASB in the slow-growth broilers partly corroborate those reported by Silva et al. (2005), who evaluated inclusion $(0.0,2.5,5.0,7.5,10,12.5$, and $15 \%)$ of ASB in diets formulated with corn as the main source of energy, on the performance of fast-growth broilers. The authors found that in the period from 1 to 47 days of age there was no significant effect on feed intake and weight gain; however, the ASB levels affected the feed conversion, wherein birds fed the diet containing $7.5 \%$ of inclusion of the by-product showed worse conversion than the control group $(0 \%)$.

Regarding the effect of sex on performance, males showed greater feed intake and weight gain in all evaluated phases, and better feed conversion than females in the phases from 1 to 56 and 1 to 78 days of age. The results obtained for the difference between the performance of males and females in the present research are in agreement with those reported in the literature. Dourado et al. (2009) and Del Castilho et al. (2013) also found no significant effect only on feed conversion until 21 and 28 days of age, respectively. Santos et al. (2005) found that the growth rate and feed conversion of males and females of slow-growth lines are similar until 21 days of age and start to differ after the 28th day.

Researchers normally associate this of the results obtained for each sex to the physiologic differences between sexes, in which males show a more accelerated growth, with better use efficiency of the food, and consequently better feed conversion. Gonzales and Sartori (2002) reported that the differences found between males and females regarding the muscular development of broilers have a significant influence of hormonal factors, and thus, because males have more androgynous hormones responsible for the muscle anabolism they have a higher growth rate than females.

Mendes, Naas and Macari (2004) also state that females have shorter muscle fibers than males at the same age, such that the increase in the fiber diameter due to constant muscle exercise differs according to the sex, but it is greater in the male sex. In addition, males have longer small and large intestines, which provides them with a better nutrient-absorption ability, which explains the higher WG and FC than females (Takahashi et al., 2006). 


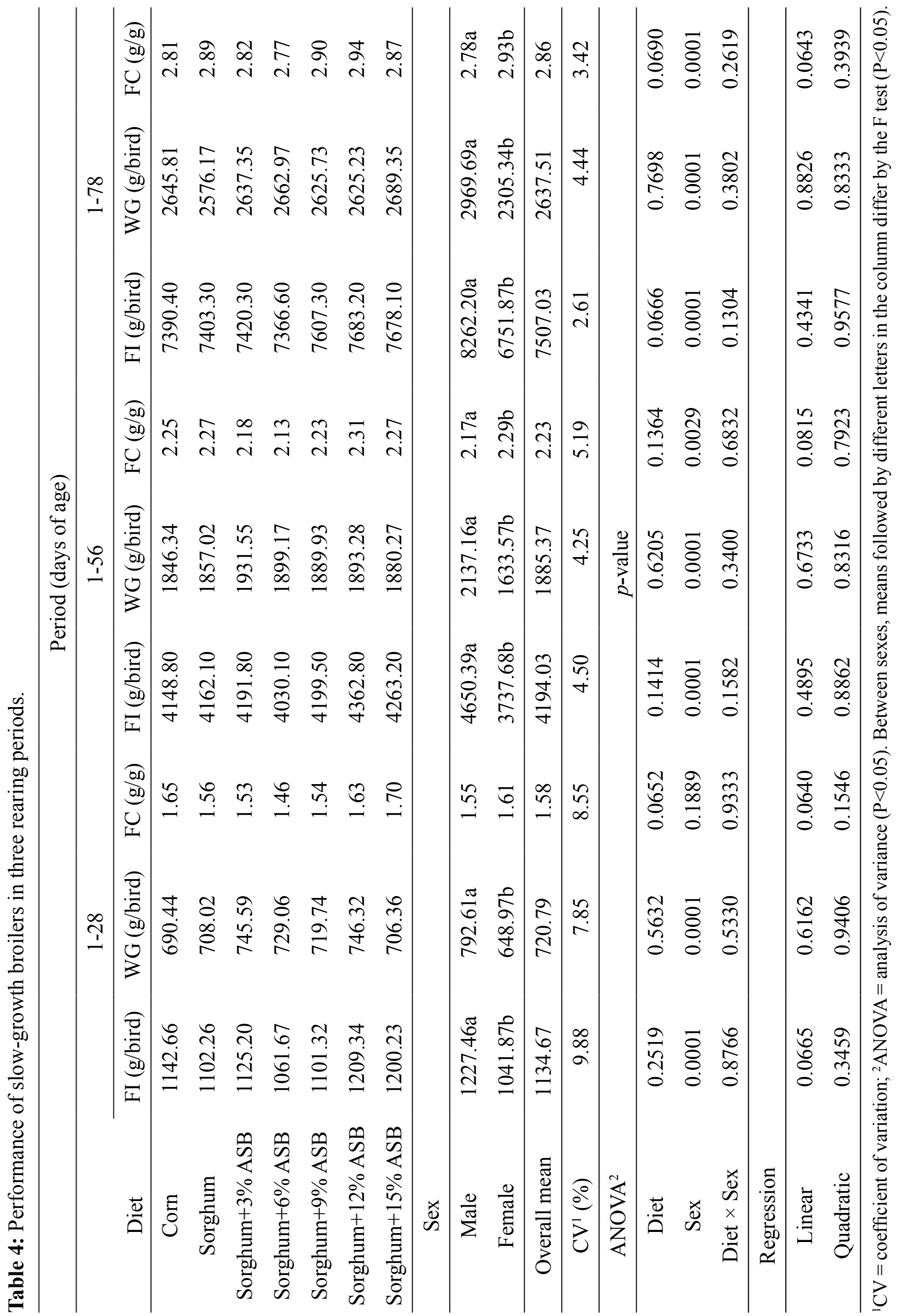


For the carcass characteristics (Table 5), it was found that there was no significant interaction between factors, sex, and diets on any of the evaluated parameters. It was also observed that treatments did not influence the evaluated carcass characteristics significantly. However, in the comparison between sexes, it was observed that carcass yield was not different between males and females, though females showed a greater yield of breast, percentage of abdominal fat, and relative weight of liver, whereas males showed a greater yield of drumstick+thigh.

The results obtained in the present study for the total substitution of corn by sorghum are similar to those reported in the literature. According to Garcia et al. (2005), substituting corn by sorghum in broiler diets up to $100 \%$ did not cause significant differences in the yields of carcass, breast, and legs (drumstick+thigh).

However, the results obtained with inclusion of ASB partly differ from those obtained by Silva et al.
(2005). Although no significant effect was found on the percentage of abdominal fat of chickens, the researchers observed a linear decrease in the yield of carcass and percentage of drumstick as the level of ASB in the diet was elevated. The authors associated this result for carcass and cuts' yields with the increase in the proportion of the birds' gastrointestinal tract resulting from the increased dietary fiber caused by the elevation of the ASB level.

Effects inherent to the sexual dimorphism on yield variables of carcasses from slow-growth lines have also been reported by other researchers. Santos et al. (2005), Takahashi et al. (2006), Dourado et al. (2009), and Del Castilho et al. (2013) found that there was no significant difference in carcass yield between the sexes, but breast yield was higher for females and drumstick+thigh yield was higher in males. Higher relative weight of abdominal fat in females was observed by Santos et al. (2005) and Campello et al. (2009).

Table 5: Carcass characteristics of slow-growth broilers at 78 days of age.

\begin{tabular}{|c|c|c|c|c|c|}
\hline \multirow[b]{2}{*}{ Diet } & \multicolumn{5}{|c|}{ Parameter (\%) } \\
\hline & Carcass & Breast & Drumstick+thigh & Liver $^{3}$ & Abdominal fat \\
\hline Corn & 73.50 & 29.19 & 32.64 & 1.32 & 2.65 \\
\hline Sorghum & 73.75 & 28.22 & 32.00 & 1.28 & 3.12 \\
\hline Sorghum $+3 \%$ ASB & 74.94 & 28.68 & 31.94 & 1.29 & 3.39 \\
\hline Sorghum $+6 \%$ ASB & 74.40 & 29.13 & 31.11 & 1.32 & 3.43 \\
\hline Sorghum $+9 \%$ ASB & 74.14 & 28.36 & 32.16 & 1.32 & 3.47 \\
\hline Sorghum $+12 \%$ ASB & 73.41 & 27.75 & 32.07 & 1.29 & 3.63 \\
\hline Sorghum $+15 \%$ ASB & 73.70 & 29.02 & 32.56 & 1.32 & 2.95 \\
\hline \multicolumn{6}{|l|}{ Sex } \\
\hline Male & 74.17 & $28.17 \mathrm{~b}$ & $33.31 \mathrm{a}$ & $1.27 \mathrm{~b}$ & $2.70 \mathrm{~b}$ \\
\hline Female & 73.78 & $29.07 \mathrm{a}$ & $30.82 b$ & $1.34 \mathrm{a}$ & $3.77 \mathrm{a}$ \\
\hline Mean & 73.98 & 28.62 & 32.07 & 1.31 & 3.23 \\
\hline $\mathrm{CV}^{1}(\%)$ & 1.77 & 3.96 & 2.97 & 8.44 & 20.81 \\
\hline ANOVA $^{2}$ & \multicolumn{5}{|c|}{$p$-value } \\
\hline Diet & 0.4079 & 0.2706 & 0.1692 & 0.9895 & 0.1976 \\
\hline Sex & 0.3506 & 0.0152 & 0.0001 & 0.0269 & 0.0001 \\
\hline Diet $\times$ Sex & 0.6027 & 0.1641 & 0.2357 & 0.7869 & 0.1698 \\
\hline \multicolumn{6}{|l|}{ Regression } \\
\hline Linear & 0.0631 & 0.7094 & 0.3327 & 0.8772 & 0.5788 \\
\hline Quadratic & 0.5506 & 0.4226 & 0.5811 & 0.9270 & 0.3615 \\
\hline
\end{tabular}

${ }^{1} \mathrm{CV}=$ coefficient of variation; ${ }^{2} \mathrm{ANOVA}=$ analysis of variance $(\mathrm{P}<0.05) ;{ }^{3}$ Ratio between weight of the organ and weight of the fasted live bird. Between sexes, means followed by different letters in the column differ by the $\mathrm{F}$ test $(\mathrm{P}<0.05)$. 
The higher relative weight of the liver observed in females may be directly associated with the greater deposition of abdominal fat in these birds. The development of the liver might have occurred due to the greater activity of this organ, since it participates actively in the lipid metabolism, or even by the deposition of a portion of available fat in the hepatocytes, for stocking. The differences in carcass characteristics, deposition of fat, and size of organs between the sexes may stem from different development patterns of the body tissues associated with the hormonal activity of each sex, as previously described for other species (Mahgoub et al., 2004).

Based on the average results obtained for the meat color parameters - L* (lightness), a* (red color intensity), and $\mathrm{b}^{*}$ (yellow color intensity) - of the breast and thigh of birds subjected to the different treatments
(Table 6), there was no significant interaction between the factors sex and diet on any of the color parameters evaluated in the birds' breast and thigh. in addition there was no significant difference between sexes for the meat color parameters. Yet, diets had a significant effect on the $\mathrm{L}^{*}, \mathrm{a}^{*}$, and $\mathrm{b}^{*}$ of the breast and thigh.

The lightness $\left(\mathrm{L}^{*}\right)$ of the breast of the poultry fed the diet containing corn as the main source of energy was similar to that of the meat from the birds fed the sorghum-based diet without addition of ASB. Regarding the thigh, however, the birds fed sorghum without ASB showed a higher $L^{*}$ value, indicating that their meat was less dark than those of the broilers fed corn. Addition of ASB at all levels resulted in a lower $\mathrm{L}^{*}$ value for breast and thigh as compared with the meat from birds fed diets based on corn or sorghum without inclusion of ASB.

Table 6: Mean values for lightness ( $\left.\mathrm{L}^{*}\right)$ and intensity of the red $\left(\mathrm{a}^{*}\right)$ and yellow $\left(\mathrm{b}^{*}\right)$ colors of breast and thigh from slow-growth broilers.

\begin{tabular}{ccccccc}
\hline & \multicolumn{3}{c}{ Breast } & \multicolumn{3}{c}{ Thigh } \\
\cline { 2 - 7 } Diet & $\mathrm{L}^{*}$ & $\mathrm{a}^{*}$ & $\mathrm{~b}^{*}$ & $\mathrm{~L}^{*}$ & $\mathrm{a}^{*}$ & $\mathrm{~b}^{*}$ \\
\hline Corn & $54.22 \mathrm{a}$ & $1.48 \mathrm{a}$ & $6.56 \mathrm{a}$ & $51.67 \mathrm{~b}$ & $1.63 \mathrm{a}$ & $4.05 \mathrm{bc}$ \\
Sorghum & $55.32 \mathrm{a}$ & $1.08 \mathrm{~b}$ & $3.35 \mathrm{c}$ & $53.93 \mathrm{a}$ & $1.05 \mathrm{~b}$ & $3.46 \mathrm{c}$ \\
Sorghum+3\% ASB & $51.93 \mathrm{~b}$ & $1.48 \mathrm{a}$ & $5.03 \mathrm{~b}$ & $49.93 \mathrm{c}$ & $1.55 \mathrm{a}$ & $3.72 \mathrm{c}$ \\
Sorghum+6\% ASB & $51.61 \mathrm{~b}$ & $1.51 \mathrm{a}$ & $5.55 \mathrm{ab}$ & $49.67 \mathrm{c}$ & $1.64 \mathrm{a}$ & $3.97 \mathrm{bc}$ \\
Sorghum+9\% ASB & $51.29 \mathrm{~b}$ & $1.53 \mathrm{a}$ & $5.80 \mathrm{ab}$ & $47.63 \mathrm{~d}$ & $1.66 \mathrm{a}$ & $4.11 \mathrm{bc}$ \\
Sorghum+12\% ASB & $48.67 \mathrm{c}$ & $1.54 \mathrm{a}$ & $5.95 \mathrm{ab}$ & $47.30 \mathrm{~d}$ & $1.76 \mathrm{a}$ & $4.43 \mathrm{ab}$ \\
Sorghum+15\% ASB & $46.98 \mathrm{c}$ & $1.60 \mathrm{a}$ & $6.39 \mathrm{a}$ & $46.53 \mathrm{~d}$ & $1.90 \mathrm{a}$ & $4.79 \mathrm{a}$ \\
\hline Sex & & & & & \\
\hline Male & 51.31 & 1.49 & 5.39 & 49.75 & 1.65 & 4.05 \\
Female & 51.55 & 1.47 & 5.67 & 49.30 & 1.64 & 4.07 \\
\hline Mean & 51.43 & 1.48 & 5.49 & 49.52 & 1.65 & 4.06 \\
\hline CV $\left.{ }^{1} \%\right)$ & 2.69 & 10.88 & 8.40 & 2.13 & 10.09 & 7.04 \\
\hline ANOVA ${ }^{2}$ & \multicolumn{7}{c}{$p$-value } & & \\
\hline Diet & 0.0001 & 0.0144 & 0.0001 & 0.0001 & 0.0007 & 0.0001 \\
Sex & 0.6461 & 0.2469 & 0.0639 & 0.2729 & 0.5579 & 0.8564 \\
Diet $\times$ Sex & 0.9202 & 0.2354 & 0.0741 & 0.0725 & 0.7701 & 0.1849 \\
\hline Regression & \multicolumn{7}{c}{0.0296} \\
\hline Linear & 0.0001 & 0.4291 & 0.0004 & 0.0003 & 0.0001 \\
Quadratic & 0.0684 & 0.9414 & 0.8851 & 0.7841 & 0.5896 & 0.5302 \\
\hline
\end{tabular}

${ }^{1} \mathrm{CV}=$ coefficient of variation; ${ }^{2} \mathrm{ANOVA}=$ analysis of variance $(\mathrm{P}<0.05)$. Between diets, means followed by different letters in the column differ by the SNK test $(\mathrm{P}<0.05)$. 
The $\mathrm{a}^{*}$ values from breast and thigh did not differ between the birds fed diet containing corn without addition of ASB and those fed diets containing sorghum with levels of the by-product; however, the sorghum-based diet without the pigmenting agent provided a lower red color intensity $\left(\mathrm{a}^{*}\right)$ for both parts, which confirms the sorghum pigmentation deficiencies.

The proportion of yellow color $\left(b^{*}\right)$ in the breast of birds fed the diet containing corn as the main source of energy was higher than that of the meat from birds fed the sorghum-based diet without addition of ASB. In the thigh, however, $b^{*}$ values did not differ among these treatments, though a higher value was recorded for the diet with corn. In the sorghum-containing diets, inclusion of ASB from 3\% led to a higher $b^{*}$ value in the breast as compared with the diet containing sorghum without ASB, while in the thigh this difference was only significant with inclusion from $12 \%$. Regarding the meat from birds fed the diet containing corn, inclusion of ASB provided similar values for yellow color intensity $\left(b^{*}\right)$ from $6 \%$ in the breast, and after 3\% in the thigh. In the thigh, the $b^{*}$ value for inclusion of $15 \%$ of ASB was higher than that obtained with the diet containing corn.

Based on the regression analysis, the ASB at levels above $3 \%$ in sorghum-containing diets provided a linear decrease in $\mathrm{L}^{*}$ values of both breast $(\mathrm{Y}=53.948-1.284 \mathrm{X}$; $\left.\mathrm{R}^{2}=0.87\right)$ and thigh $\left(\mathrm{Y}=50.963-0.917 \mathrm{X} ; \mathrm{R}^{2}=0.93\right)$, a linear increase in the $b^{*}$ values of the breast $(\mathrm{Y}=4.808$ $\left.+0.312 \mathrm{X} ; \mathrm{R}^{2}=0.96\right)$ and thigh $\left(\mathrm{Y}=3.424+0.26 \mathrm{X} ; \mathrm{R}^{2}=\right.$ 0.98 ), and a linear increase in the $\mathrm{a}^{*}$ values only for thigh $\left(\mathrm{Y}=1.460+0.08 \mathrm{X} ; \mathrm{R}^{2}=0.95\right)$. These results indicate that ASB has a positive pigmenting effect on the meat of slow-growth birds fed diets containing sorghum as the main source of energy.

Contrary to the present study, Silva et al. (2005) reported that no effect of ASB was detected on the carcass pigmentation measured in the skin of the leg by the color-fan visual method. It should be noted that the researchers employed the inclusion of ASB in diets formulated with corn as the main source of energy. Harder et al. (2010), in turn, reported the pigmenting potential of annatto seed, which improved the color of chicken meat after cooking. According to the authors, addition of $3 \%$ annatto seed led to a lower lightness ( $\mathrm{L}^{*}$ ) value in the breast, indicating a darker meat than that from birds fed diets based on corn and soybean meal without addition of annatto. Although no significant difference occurred, parameters $\mathrm{a}^{*}$ and $\mathrm{b}^{*}$ of the breast were also higher for the birds fed diets containing 3\% ASB. For the drumstick, researchers reported higher $b^{*}$ value with inclusion of $3 \%$ ASB without significant differences between the treatments for the $\mathrm{L}^{*}$ and $\mathrm{a}^{*}$ values.

Considering the results obtained in this study and those reported by Harder et al (2010), it can be inferred that the darkening (lower lightness) of the color of the meat from the birds fed the diets containing sorghum and levels of ASB occurred mainly due to the significant increase in the proportion of the yellow $\left(b^{*}\right)$ color of the meat, since it was not as expressive for the red color $\left(\mathrm{a}^{*}\right)$. This response regarding the effects of the annatto seed products on the meat color differ partly from those reported about the effects of these products on the yolk color, since besides reducing lightness $\left(\mathrm{L}^{*}\right)$, the addition of annatto seed increased the $a^{*}$ and $b^{*}$ values (Hader et al., 2007; Garcia et al., 2009).

Nevertheless, it can be affirmed that the total substitution of corn by sorghum in the diets for slowgrowth birds does not affect their performance and carcass characteristics, but may reduce the meat color tone. Thus, given that this type of bird has been raised to meet a market niche in which consumers seek meat with differentiated attributes, especially tougher texture and darker color, the total substitution of corn for sorghum is unfeasible. The inclusion of ASB from 3\% in diets containing sorghum as the main source of energy, however, may solve the meat pigmentation problem, and its inclusion as an ingredient can reach $15 \%$.

With regard to the economic viability (Table 7), it was observed that there was no significant interaction between the factors sex and diets on any of the evaluated parameters; however, the cost of diet (CD), the economic efficiency index (EEI), and the cost index (CI) varied significantly between the sexes and among the diets received by the birds. The diet containing corn resulted in a higher $\mathrm{CD}$ and worse EEI and CI as compared with the others. However, there was no significant difference between the $\mathrm{CD}$, EEI and CI values for the diets containing sorghum and the different levels of inclusion of ASB.

This result demonstrates the economic viability of substituting corn for sorghum in the feeding of these birds and including ASB to solve the meat pigmentation problem due to the total substitution of corn for sorghum in the diet. As for the effect of sex, males showed a lower $\mathrm{CD}$, higher EEI, and lower CI than females, which was an expected result given the different physiology, use of nutrients, and the growth rate reported previously between the sexes. 
Table 7: Economic evaluation of the use of sorghum and annatto seed by-product in diets for slow-growth broilers.

\begin{tabular}{|c|c|c|c|}
\hline \multirow[b]{2}{*}{ Diet } & \multicolumn{3}{|c|}{ Parameter } \\
\hline & $\mathrm{CD}^{1}(\mathrm{R} \$ / \mathrm{kg}$ gained $)$ & $\mathrm{EEI}^{2}(\%)$ & $\mathrm{CI}^{3}(\%)$ \\
\hline Corn & $3.22 \mathrm{a}$ & $87.33 b$ & $115.00 \mathrm{a}$ \\
\hline Sorghum & $2.92 b$ & $96.33 \mathrm{a}$ & $104.50 \mathrm{~b}$ \\
\hline Sorghum $+3 \%$ ASB & $2.88 \mathrm{~b}$ & $97.33 \mathrm{a}$ & $102.83 b$ \\
\hline Sorghum $+6 \%$ ASB & $2.80 \mathrm{~b}$ & $100.17 \mathrm{a}$ & $100.00 \mathrm{~b}$ \\
\hline Sorghum $+9 \%$ ASB & $2.96 b$ & $94.83 \mathrm{a}$ & $105.50 \mathrm{~b}$ \\
\hline Sorghum $+12 \%$ ASB & $2.98 b$ & $94.00 \mathrm{a}$ & $106.40 \mathrm{~b}$ \\
\hline Sorghum $+15 \%$ ASB & $2.93 b$ & $95.67 \mathrm{a}$ & $104.50 \mathrm{~b}$ \\
\hline \multicolumn{4}{|l|}{ Sex } \\
\hline Male & $2.87 \mathrm{~b}$ & $97.67 \mathrm{a}$ & $102.62 b$ \\
\hline Female & $3.04 \mathrm{a}$ & $92.45 b$ & $108.55 \mathrm{a}$ \\
\hline Mean & 2.96 & 95.12 & 105.51 \\
\hline $\mathrm{CV}^{4}(\%)$ & 3.84 & 3.73 & 3.94 \\
\hline ANOVA $^{5}$ & & $p$-value & \\
\hline Diet & 0.0001 & 0.0001 & 0.0001 \\
\hline Sex & 0.0001 & 0.0001 & 0.0001 \\
\hline Diet $\times$ Sex & 0.1134 & 0.2246 & 0.1581 \\
\hline \multicolumn{4}{|l|}{ Regression } \\
\hline Linear & 0.0708 & 0.0722 & 0.0788 \\
\hline Quadratic & 0.7023 & 0.7467 & 0.6919 \\
\hline
\end{tabular}

${ }^{1} \mathrm{CD}=$ cost of diet; ${ }^{2} \mathrm{EEI}=$ economic efficiency index; ${ }^{3} \mathrm{CI}=$ cost index; ${ }^{4} \mathrm{CV}=$ coefficient of variation; ${ }^{5} \mathrm{ANOVA}=$ analysis of variance $(\mathrm{P}<0.05)$. Between diets, means followed by different letters in the column differ by the $\mathrm{SNK}$ test $(\mathrm{P}<0.05)$. Between sexes, means followed by different letters in the column differ by the SNK test $(\mathrm{P}<0.05)$.

\section{CONCLUSION}

Up to $15 \%$ ASB can be included in diets for slowgrowth birds containing sorghum as the main source of energy, and meat pigmentation problems can be reduced with total substitution of corn by sorghum and inclusion of ASB from 3\%.

\section{ACKNOWLEDGMENT}

To Banco do Nordeste do Brasil (BNB) for financing the research project.

\section{REFERENCES}

BELLAVER, C. et al. Radícula de malte na alimentação de suínos em crescimento e terminação. Pesquisa Agropecuária Brasileira. 20(8):969-974, 1985.

CAMPELLO, C. C. et al. Características de carcaça de frangos tipo caipira alimentados com dietas contendo farinha de raízes de mandioca. Ciência Animal

Brasileira. 10(4):1021-1028, 2009.

DEL CASTILHO, C. C. et al. Effects of sex and genotype on performance and yield characteristics of free range broiler chickens. Arquivo Brasileiro de Medicina Veterinária e Zootecnia. 65(5):1483-1490, 2013.

DOURADO, L. R. B. et al. Crescimento e desempenho de linhagens de aves pescoço pelado criadas em sistema semi-confinado. Ciência e Agrotecnologia. 33(3):875881, 2009.

FIALHO, E.T. et al. Utilização da cevada suplementada com óleo de soja para suínos em crescimento e terminação. Pesquisa Agropecuária Brasileira. 27(10):1467-1475, 1992. 
FREITAS, E. R. et al. Substituição do farelo de soja pelo farelo de coco em rações contendo farelo da castanha de caju para frangos de corte. Revista Brasileira de Zootecnia. 40(5):1006-1013, 2011.

GARCIA, R. G. et al. Desempenho e qualidade da carne de frangos de corte alimentados com diferentes níveis de sorgo em substituição ao milho. Arquivo Brasileiro de Medicina Veterinária e Zootecnia. 57(5):634-643, 2005.

Desempenho e qualidade dos ovos de poedeiras comerciais alimentados semente de urucum (Bixa orellana L.) moída na dieta. Veterinária e Zootecnia. 16(4):689-697, 2009.

GOMES, F. A. et al. Valores energéticos de alguns alimentos utilizados em rações para codornas japonesas. Revista Brasileira de Zootecnia. 36(2):396-402, 2007.

GONZALES, E.; SARTORI, J. R. Crescimento e metabolismo muscular. In: MACARI, M.; FURLAN, R. L.; GONZALES, E. Fisiologia aviária aplicada a frangos de corte. Jaboticabal: FUNEP/UNESP, 2002. v.1, p.279-297.

HARDER, M. N. C. et al. Coloração de cortes cozidos de frangos alimentados com urucum. Ciência e Tecnologia de Alimentos. 30(2):507-509, 2010.

MAHGOUB, O. et al. Effects of body weight and sex on carcass tissue distribution in goats. Meat Science. 67(4):577-585, 2004.

MENDES, A. A.; NAAS, I. A.; MACARI, M. Produção de Frangos de Corte. Campinas: FACTA, 2004. 356 p.

MORENO, J. O. et al. Desempenho e qualidade dos ovos de poedeiras comerciais, alimentadas com dietas contendo sorgo e páprica em substituição ao milho.

Acta Scientiarum. Animal Science. 29(2):159-163, 2007.
NATIONAL RESEARCH COUNCIL - NRC. Nutrient requirements of poultry. $9 \mathrm{ed}$. Washington, D. C.: National Academy of Sciences: 1994. 155 p.

ROCHA, V. R. R. A. et al. Substituição total do milho por sorgo e óleo de abatedouro avícola em dietas para frangos de corte. Revista Brasileira de Zootecnia. 37(1):95-102, 2008.

ROSTAGNO, H. S. et al. Tabelas Brasileiras para aves e suínos: Composição de alimentos e exigências nutricionais. 3.ed. Viçosa, MG: Universidade Federal de Viçosa, 2011.252 p.

SANTOS, A. L. et al. Estudo do crescimento, desempenho, rendimento de carcaça e qualidade de carne de três linhagens de frango de corte. Revista Brasileira de Zootecnia. 34(5):1589-1598, 2005.

SAS Institute. SAS Users guide: Statistics. Version 8. Carry, NC, 2000.

SHIMOKOMAKI, M. et al. Atualidades em ciência e tecnologia de carnes. São Paulo: Livraria Varela, 2006. $236 \mathrm{p}$.

SILVA, J. H. V. et al. Efeitos da inclusão do resíduo da semente de urucum (Bixa orellana L.) na dieta para frangos de corte: Desempenho e características de carcaça. Revista Brasileira de Zootecnia. 34(5):16061613, 2005.

. Resíduo da semente de urucum

(Bixa orellana L.) como corante da gema, pele, bico e ovário de poedeiras avaliado por dois métodos analíticos. Ciência e Agrotecnologia. 30(5):988-994, 2006.

TAKAHASHI, S. E. et al. Efeito do sistema de criação sobre o desempenho e rendimento de carcaça de frangos de corte tipo colonial. Arquivo Brasileiro de Medicina Veterinária e Zootecnia. 58(4):624-632, 2006. 